\title{
Modelling of Drying Curves of Spruce, Beech, Willow and Alder Particles
}

\section{Modeliranje krivulja sušenja iverja od drva smreke, bukve, vrbe i johe}

\author{
Original scientific paper • Izvorni znanstveni rad \\ Received-prispjelo: 11. 1. 2016. \\ Accepted-prihvaćeno: 15. 11. 2016. \\ UDK: $630 * 861.02 ; 630 * 863.212 ; 674.032 .13 ; 674.031 .632 .22 ; 674.031 .623 .22 ; 674.031 .623 .15$ \\ doi:10.5552/drind.2017.1602
}

\begin{abstract}
Drying behaviour of spruce (Picea abies (L.) H. Karst.), beech (Fagus sylvatica L.), willow (Salix alba L.), and alder (Alnus glutinosa (L.) Gaertn.) particles was investigated in a convective dryer at constant air velocity of $0.01 \mathrm{~m} / \mathrm{s}$ and at the drying air temperature of $25,60,80$, and $150^{\circ} \mathrm{C}$. The results of the experiments have shown that the wood species and drying air temperature influence the drying behaviour. The experimental drying data of wood particles obtained were fitted to six empirical models. The effects of wood species and drying air temperature on the drying model parameters were determined. The accuracy of the models was measured using the determination coefficient $\left(R^{2}\right)$, root mean square error (RMSE), and reduced chi-square $\left(\chi^{2}\right)$. The results showed that Lewis model, Henderson and Pabis model, and modified Page model, with the model parameters determined taking into account the effect of wood species and of drying air temperature, were found to satisfactorily describe the drying curves of spruce, beech, willow, and alder particles.
\end{abstract}

Key words: wood species, particles, drying kinetics, drying temperature, modelling

SAŽETAK • U radu su prikazani rezultati istraživanja procesa sušenja iverja od drva smreke (Picea abies (L.) H. Karst.), bukve (Fagus sylvatica L.), vrbe (Salix alba L.) i johe (Alnus glutinosa (L.) Gaertn.) u konvekcijskoj sušionici pri konstantnoj brzini zraka od $0,01 \mathrm{~m} / \mathrm{s}$ i pri temperaturi zraka $25,60,80$ i $150{ }^{\circ} \mathrm{C}$. Rezultati pokusa pokazali su da vrsta drva i temperatura zraka utječu na tijek procesa sušenja drvnog iverja. Podaci dobiveni sušenjem iverja analizirani su s pomoću šest empirijskih modela. Određen je učinak vrste drva i temperature zraka na parametre modela sušenja. Točnost modela mjerena je veličinom koeficijenta determinacije $\left(R^{2}\right)$, korijena srednje vrijednosti kvadrata pogreške (RMSE) i reduciranog hi-kvadrata $\left(\chi^{2}\right)$. Rezultati su pokazali da se krivulje sušenja iverja od drva smreke, bukve, vrbe i johe na zadovoljavajući način mogu opisati primjenom Lewisova modela, Hendersonova i Pabisova modela te modificiranoga Pageova modela s parametrima određenima tako da se uzmu u obzir utjecaj vrste drva i temperature zraka pri sušenju iverja.

Ključne riječi: vrsta drva, iverje, kinetika sušenja, temperatura sušenja, modeliranje

\footnotetext{
${ }^{1}$ Authors are associate professor, professor and PhD students at Department of Fundamental Engineering, Faculty of Production Engineering, Warsaw University of Life Sciences, Warszawa, Poland.

Autori su izvanredni profesor, profesorica i doktorandi Odsjeka za temeljno inženjerstvo, Fakultet proizvodnog inženjerstva, Sveučilište prirodnih znanosti u Varšavi, Varšava, Poljska.
} 


\section{INTRODUCTION}

\section{UVOD}

Drying of wood particles is one of the main steps not only in a particleboard production process but also in biofuel (pellets and briquettes) production process. For pellet production, the wood must be dried to the range 0.09-0.14 kg H $\mathrm{O} / \mathrm{kg}$ d.m. (dry matter) moisture content (Ståhl et al., 2004). Consumption of high amount of energy, apart from environmental impacts, makes drying one of the most energy intensive operations with a great importance in particleboard, pellet and briquette manufacturing. Hence, reducing energy consumption, besides product quality, would be highly important for drying the raw materials used in industry (Zarea Hosseinabadi et al., 2012). Improvements in the wood drying process are accompanied by better understanding of the drying process (Kohantorabi et al., 2015).

Wood drying is a complex process of heat and mass transfer, which is conditioned by some phenomena, such as heat/moisture exchange between wood and environment, and heat/moisture movement in wood (Kajalavičius, 2008). It can be stated that this technological process is based on considerably complicated hydro-thermal process and, despite the noticeable effort of scientists and technologists, it has not yet been fully clarified (Dzurenda and Deliiski, 2012).

Investigation of drying kinetics is one of the best methods to get sufficient information about drying performance. Experimental data from the drying curves can be used in simulation of wood particle drying to optimize the particleboard and biofuel production processes (Zarea Hosseinabadi et al., 2012).

An important aspect of drying technology is the mathematical modelling of the drying process. Mathematical modelling provides a tool to enable drying rate and efficiency to be predicted under a range of conditions. Scientists developed various mathematical models on the basis of which it would be possible to predict wood moisture content under changing conditions and moisture movement in wood (Turner, 1996; Gigler et al., 2000; Truscott and Turner, 2005; Deliiski and Syuleymanov, 2006; Zarea Hosseinabadi et al., 2012). To account for the effect of drying variables on the drying model constants and coefficients, the predicted values were also correlated as a function of drying air temperature and air flow velocity (Zarea Hosseinabadi et al., 2012) or initial material load, particle shape and size (Kaleta and Górnicki, 2010). There is, however, no information on the investigation of the effect of wood species on the drying models constants and coefficients. Therefore, the aim of the present study was to investigate the effect of wood species and of drying air temperature on the drying model parameters.

\section{MATERIALS AND METHODS 2. MATERIJALI I METODE \\ 2.1 Raw material \\ 2.1. Sirovina}

In this research, sawdust of spruce (Picea abies (L.) H. Karst.), beech (Fagus sylvatica L.), willow (Sa- lix alba L.), and alder (Alnus glutinosa (L.) Gaertn.) was used in the drying experiments. Sawdust was obtained from a sawmill. The size distribution of raw material determined through screen analysis was as follows: the size of $86 \%$ of all particles for spruce, $82 \%$ for beech, $84 \%$ for willow, and $77 \%$ for alder was less than $10 \mathrm{~mm}$ and bigger than $0.5 \mathrm{~mm}$. Sawdust particles totalling $14 \%$ for spruce, $18 \%$ for beech, $16 \%$ for willow, and $23 \%$ for alder passed through the $0.5 \mathrm{~mm}$ screen. The initial moisture content of samples ranged from: 0.45 to $0.49 \mathrm{~kg} \mathrm{H} \mathrm{O} / \mathrm{kg} \mathrm{d} . \mathrm{m}$. for spruce, 0.85 to $0.90 \mathrm{~kg} \mathrm{H} \mathrm{H}_{2} \mathrm{O} / \mathrm{kg}$ d.m. for beech, 0.77 to $0.82 \mathrm{~kg} \mathrm{H} \mathrm{H}_{2} \mathrm{O} /$

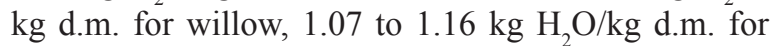
alder.

\subsection{Drying procedure \\ 2.2. Postupak sušenja}

The drying experiments were carried out using Memmert UFP400 (MEMMERT GmbH+Co. KG, Schwabach, Germany) laboratory dryer. The drying experiments were conducted at the drying air temperature of $25,60,80$, and $150{ }^{\circ} \mathrm{C}$ and airflow velocity of $0.01 \mathrm{~m} / \mathrm{s}$. Measurements of the moisture content changes carried out in the laboratory dryer were conducted in the following way. The sample was put on the tulle stretched on the metal frame (scale) and hung up to the electronic scales WPX 650 (RADWAG, Radom, Poland). The accuracy of the weighing was \pm 1 $\mathrm{mg}$. Computer connected to the scales was an additional equipment of experimental stand. It recorded the mass of dried sample at regular intervals of $60 \mathrm{~s}$. Measurements of mass changes were recorded up to the moment, when the mass changes of the sample were not observed. Experiments were replicated three times.

Air temperature inside the dryer was measured with $\pm 0.1{ }^{\circ} \mathrm{C}$ accuracy using thermocouple TP-01b-W3 (NiCr-NiAl, CZAKI THERMO-PRODUCT, Raszyn, Poland), placed at the central part of dryer chamber. Temperature reading was done with EMT-08 meter (CZAKI THERMO-PRODUCT, Raszyn, Poland). The velocity of drying air was measured with $\pm 3 \%$ accuracy using Kestrel ${ }^{\circledR} 4000$ Packet Weather ${ }^{\mathrm{TM}}$ Tracker $^{\mathrm{TM}}$ (Nielsen-Kellerman Company, Boothwyn, PA, USA).

The initial and final moisture contents of sawdust were determined using the oven method (ASAE, 1994).

\subsection{Mathematical modelling of drying and data analysis}

2.3. Matematičko modeliranje procesa sušenja i analiza podataka

Table 1 indicates the models used to describe the drying kinetics of wood particles, where $a, b, k, n$ are constants of the models and $t$ is the time. The dimensionless moisture ratio $\mathrm{MR}$ is given by

$$
\mathrm{MR}=\frac{M_{\mathrm{t}}-M_{\mathrm{e}}}{M_{0}-M_{\mathrm{e}}}
$$

Where $M_{\mathrm{t}}$ is the moisture content at $t, M_{\mathrm{e}}$ is the equilibrium moisture content, and $M_{0}$ is the initial moisture content. Moisture contents are on dry basis.

The models applied are empirical models. From the practical point of view, the simple models having 
...... Górnicki, Kaleta, Bryś, Winiczenko: Modelling of Drying Curves of Spruce, Beech...

Table 1 Models applied to drying curves

Tablica 1. Modeli primijenjeni za krivulje sušenja

\begin{tabular}{|c|c|c|c|}
\hline $\begin{array}{c}\text { Model No. } \\
\text { Broj modela }\end{array}$ & $\begin{array}{c}\text { Model equation } \\
\text { Jednadžba modela }\end{array}$ & $\begin{array}{c}\text { Model name } \\
\text { Naziv modela }\end{array}$ & Reference / Izvor \\
\hline 1 & $\mathrm{MR}=\exp (-k \cdot t)$ & Lewis (Newton) & Lewis, 1921 \\
\hline 2 & $\mathrm{MR}=a \cdot \exp (-k \cdot t)$ & Henderson and Pabis & Henderson and Pabis, 1961 \\
\hline 3 & $\mathrm{MR}=\exp \left(-k \cdot t^{n}\right)$ & Page & Page, 1949 \\
\hline 4 & $\mathrm{MR}=\exp \left[-\left(k \cdot t^{n}\right)\right]$ & Modified Page & Overhults et al., 1973 \\
\hline 5 & $\mathrm{MR}=1+a \cdot t+b \cdot t^{2}$ & Wang and Singh & Wang and Singh, 1978 \\
\hline 6 & $\mathrm{MR}=a \cdot t^{2}$ & Geometric & Chandra and Singh, 1995 \\
\hline
\end{tabular}

no more than two parameters were chosen. Although empirical models neglect the fundamentals of drying, they are easy to use because such models give a direct relationship between average moisture content and drying time. Empirical models are very often used in practical drying.

In order to determine the moisture ratio as a function of drying time, drying curves obtained in the experiments were fitted to six different models (Table 1). A non-linear regression analysis was conducted to fit the models by the Lavenberg-Marquardt method using the computer program STATISTICA 10.

The goodness of fit of each model to the experimental data was evaluated from the coefficient of determination $\left(\mathrm{R}^{2}\right)$, the root mean square error (RMSE), and reduced chi - square $\left(\chi^{2}\right)$. High values of $R^{2}$ and low values of RMSE and $\chi^{2}$ are needed to show a suitable model that describes the drying curve of wood particles (Zarea Hosseinabadi et al., 2012; Kaleta et al. 2013; Gómez-de la Cruz et al., 2015).

The effect of wood species and drying air temperature on the drying model parameters was investigated in the following way. The constants and coefficient of the models 1-6 involving the mentioned variables were determined by investigating the following type of dependences: summation $Y=f$ (wood species $)+f(\mathrm{~T})$, subtraction $Y=f($ wood species $)-f(\mathrm{~T})$, multiplication $Y=f$ (wood species) $\cdot f(\mathrm{~T})$, division $Y=$ $f$ (wood species) $/ f(\mathrm{~T})$, where $Y$ is the variable, $T$ is the temperature. The effect of the drying air temperature was determined by considering the following type of equations: linear $f(\mathrm{~T})=A+B \cdot T$, rational $f(\mathrm{~T})=A+$ $B \cdot T^{-1}$, logarithmic (natural) $f(\mathrm{~T})=A+B \cdot \ln (T)$, logarithmic (common) $f(\mathrm{~T})=A+B \cdot \log (T)$, and square $f$ (T) $=A+B \cdot T+C \cdot T^{2}$, where $A, B$, and $C$ are the coefficients independent of wood species. The effect of wood species was determined by investigating the following equation: $f$ (wood species) $=A_{w}$, where $A_{\mathrm{w}}$ is the coefficient which is independent of the drying air temperature.

\section{RESULTS AND DISCUSSION}

\section{REZULTATI I RASPRAVA}

\subsection{Drying characteristics}

3.1. Obilježja procesa sušenja

The drying of wood particles was affected by drying air temperature (Fig. 1). Each of the drying curves $M(t)$ represents an empirical formula, which approximates the results of three measurement repeti- tions of the moisture content changes with time. Each of the drying rate curves $\mathrm{d} M / \mathrm{d} t$ was obtained by differentiation of the drying curves.

Fig. 1 shows that the higher the air temperature, the shorter was the drying time and the higher was the drying rate. The following explanation of the obtained experimental results can be presented. Heat transfer rate increases with increasing of drying temperature and, therefore, the water molecules move faster. Moreover, the moisture diffusion coefficient increases with increasing of discussed temperature. Consequently, the water migration inside the product accelerates with increasing of drying temperature (Kaleemullah and Kailappan, 2005; Kashaninejad et al., 2007; Zielińska and Markowski 2007; Zarea Hosseinabadi et al., 2012). The same trends as discussed for alder (Fig. 1) were obtained for spruce, beech, and willow particles. The decrease in drying time and increase in drying rate with the increase in drying air temperature have been also observed for particles of Scots pine (Bauer, 2003) and poplar particles (Zarea Hosseinabadi et al., 2012).

The initial moisture content of the investigated wood species was different. Therefore, in order to compare the course of their drying, the moisture ratio vs. time chart is presented in Fig. 2. It can be stated that the drying of wood particles was affected by wood species. Fig. 2 shows that the shortest drying time was observed for spruce particles and the longest for beech ones. This can be explained by different densities of beech, alder, spruce, and willow. Such an explanation,

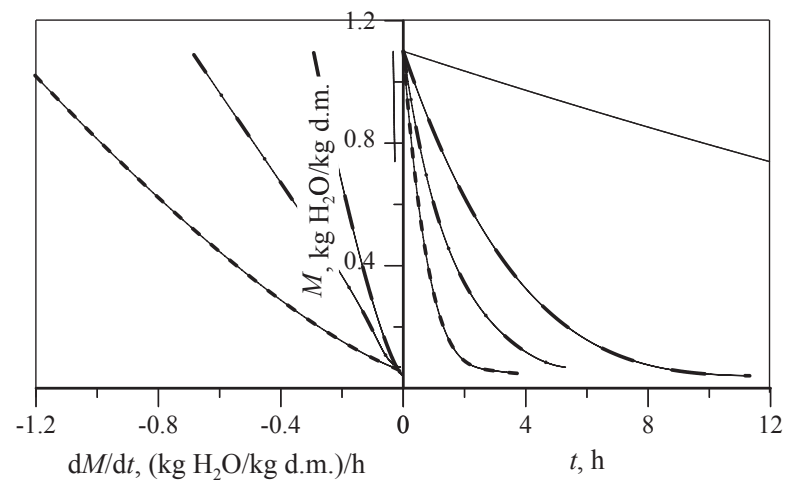

Figure 1 Moisture content vs. time and drying rate vs. moisture content for drying of alder particles at different air temperatures; $-25^{\circ} \mathrm{C},--60{ }^{\circ} \mathrm{C},-\cdots 80^{\circ} \mathrm{C},--150{ }^{\circ} \mathrm{C}$ Slika 1. Odnos sadržaja vode i vremena sušenja te odnos brzine sušenja i sadržaja vode tijekom sušenja iverja od drva johe pri različitim temperaturama zraka: $-25^{\circ} \mathrm{C},--60{ }^{\circ} \mathrm{C}$, - - - $80{ }^{\circ} \mathrm{C},--150{ }^{\circ} \mathrm{C}$ 


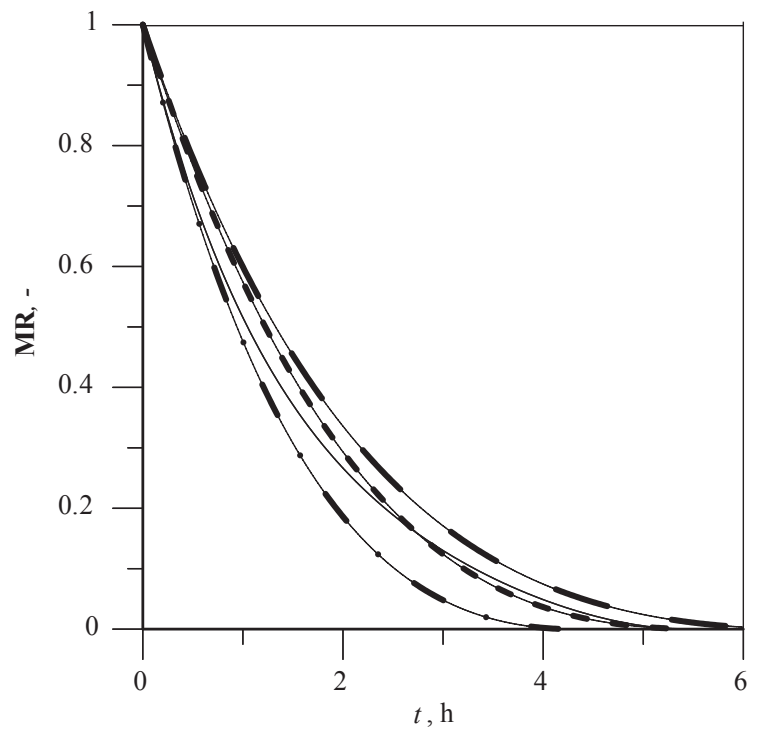

Figure 2 Moisture ratio vs. time for drying of different wood species particles at $80{ }^{\circ} \mathrm{C}$ air temperature; - alder, -beech, - - - spruce, - - - willow

Slika 2. Odnos omjera sadržaja vode i vremena sušenja za iverje od različitih vrsta drva pri temperaturi zraka $80^{\circ} \mathrm{C}$ : - joha, - - bukva, - - - smreka, - - - vrba

taking into account different densities of wood species, was given by Albrektas and Ukvalbergiené (2015) for the course of moistening process of oak, ash, and aspen wood. The explanation is as follows. In case of wood with lower density, cell cavities whose holes contain bound moisture have a relatively large internal surface. Consequently, such wood desorbs more moisture at the beginning of the drying. In present study, this can be noticed for spruce and alder. On the other hand, there is a smaller number of microcapillaries in low density wood and for this reason water migration from deeper layers becomes slower with drying duration. Desorption of moisture from wood of high density is slower and steadier. In the present study, such a situation was observed for beech particles. The same trends as discussed for drying at $80^{\circ} \mathrm{C}$ were obtained at the air temperature of 25,60 , and $150{ }^{\circ} \mathrm{C}$.

\subsection{Evaluation of the models}

\subsection{Ocjena modela}

The evaluation of the considered empirical models was conducted in the following way. The moisture content data obtained for different drying air temperatures were converted to the dimensionless moisture content expression and then curve fitting computations with the drying time were carried out using the six drying models considered above. Then the regressions were undertaken to account for the effect of wood species and drying air temperature on the drying model parameters of the six models. The effects of wood species and drying air temperature on the model parameters were also included in the models. The summation, subtraction, multiplication, and division dependences were tested. Regarding the air drying temperature, the following types of equation were used: linear, rational, logarithmic (natural), logarithmic (common), and square. The multiple combinations of the parameters that gave the highest $\mathrm{R}^{2}$-values were included in the final model. The considered equations with the determined coefficients were then used to estimate the moisture content of spruce, beech, willow, and alder particles at any time during the process. Validation of the established models was made by comparing the computed moisture content with the measured ones in any particular drying run under certain conditions.

It turned out from the statistical analyses that the models 1, 2, and 4 (Table 2) with the model parameters determined with the following type of equations: 1) summation (or subtraction) and linear, rational or logarithmic (common), 2) multiplication and square, 3) division and linear or rational can be considered as appropriate for spruce, beech, willow, and alder particles. In case of calculating the model parameters using summation (or subtraction) and square type of equation, the models 1, 2, 3, and 4 can be assumed as suitable models for describing the drying process of the considered wood particles. It can be accepted that model 1 with the model parameters determined by division and logarithmic (common) equation gave acceptable results for drying characteristics of spruce, beech, willow, and alder particles. Models 1, 2, 4, and 5 with division and square model parameters seemed to be appropriate for the examined wood particles. Taking into account values of $R^{2}, \mathrm{RMSE}$, and $\chi^{2}$, however, it can be stated that the best results of the above cases were obtained by model 1,2 , and 4 with the model parameters determined by summation (or subtraction) and linear, rational, logarithmic (common) or square type of equations.

It can be concluded from the analysis that the effect of wood species and of drying air temperature on the drying model parameters can be considered individually (Table 3 ).

By substituting the coefficients given in Table 3 into parameter equations and then substituting the discussed equations into tested models, the course of drying curve can be predicted for spruce, beech, willow, and alder particles in the temperature range of $25-150$ ${ }^{\circ} \mathrm{C}$. Obtained results can be used in practice. From the practical point of view, the used drying models need to be accurate and simple in application. Therefore, models 1 and 2 can be recommended for practical applications. The results of statistical analysis for the recommended models are as follows: model 1 (Lewis (Newton) model): $R^{2}=0.8347-0.9998$, RMSE $=$ $0.0203-0.3529, \chi^{2}=0.0002-0.1250$ and model 2 (Henderson and Pabis model): $R^{2}=0.8287-0.9998$, $\mathrm{RMSE}=0.0200-0.3229, \chi^{2}=0.0004-0.1044$.

\section{CONCLUSIONS}

4. ZAKLJUČAK

Drying behaviour of spruce, beech, willow, and alder particles was investigated in a convective dryer. The effect of wood species and air drying temperature on the drying model parameters was investigated. Six empirical models were considered. The determination coefficient $\left(R^{2}\right)$, root mean square error (RMSE), and 
...... Górnicki, Kaleta, Bryś, Winiczenko: Modelling of Drying Curves of Spruce, Beech...

Table 2 Type of parameter equation and comparison of results of statistical analysis of modelling of drying of spruce, beech, willow, and alder particles

Tablica 2. Vrsta parametarske jednadžbe i usporedba rezultata statističke analize modeliranja procesa sušenja iverja od drva smreke, bukve, vrbe i johe

\begin{tabular}{|c|c|c|c|c|}
\hline $\begin{array}{l}\text { Type of parameter equation } \\
\text { Vrsta parametarske jednadžbe }\end{array}$ & $\begin{array}{l}\text { Models No. } \\
\text { Broj modela }\end{array}$ & $R^{2}$ & RMSE & $\chi^{2}$ \\
\hline \multirow{3}{*}{$\begin{array}{l}\text { Summation (or subtraction) and linear } \\
\text { zbrajanje (ili oduzimanje) } \text { i linerna } \\
Y=A_{\mathrm{W}} \pm(A+B \cdot T)\end{array}$} & 1 & $0.9511-0.9998$ & $0.0203-0.1059$ & $0.0002-0.0112$ \\
\hline & 2 & $0.9364-0.9991$ & $0.0200-0.1072$ & $0.0004-0.0115$ \\
\hline & 4 & $0.8962-0.9920$ & $0.0515-0.1213$ & $0.0025-0.0148$ \\
\hline \multirow{3}{*}{$\begin{array}{l}\text { Summation (or subtraction) and rational } \\
\text { zbrajanje (ili oduzimanje) } \text { i racionalna } \\
Y=A_{\mathrm{W}} \pm\left(A+B \cdot T^{-1}\right)\end{array}$} & 1 & $0.9277-0.9980$ & $0.0203-0.1270$ & 0.0004-0.0161 \\
\hline & 2 & $0.9101-0.9990$ & $0.0202-0.1287$ & $0.0004-0.0166$ \\
\hline & 4 & $0.8731-0.9631$ & $0.0596-0.1421$ & $0.0035-0.0203$ \\
\hline \multirow{3}{*}{$\begin{array}{l}\text { Summation (or subtraction) and logarithmic } \\
\text { (common) } \\
\text { zbrajanje (ili oduzimanje) i logaritamska } \\
Y=A_{\mathrm{W}} \pm[A+B \cdot \log (T)]\end{array}$} & 1 & $0.9402-0.9988$ & $0.0240-0.1163$ & $0.0003-0.0135$ \\
\hline & 2 & $0.9242-0.9929$ & $0.0248-0.1179$ & $0.0004-0.0159$ \\
\hline & 4 & $0.8903-0.9782$ & $0.0529-0.1316$ & $0.0028-0.0174$ \\
\hline \multirow{4}{*}{$\begin{array}{l}\text { Summation (or subtraction) and square } \\
\text { zbrajanje (ili oduzimanje) } i \text { kvadratna } \\
Y=A_{\mathrm{w}} \pm\left(A+B \cdot T+C \cdot T^{2}\right)\end{array}$} & 1 & $0.9700-0.9997$ & $0.0335-0.0868$ & $0.0011-0.0075$ \\
\hline & 2 & $0.9603-0.9998$ & $0.0295-0.0877$ & $0.0009-0.0077$ \\
\hline & 3 & 0.8906-0.9759 & $0.0526-0.1252$ & $0.0027-0.0157$ \\
\hline & 4 & 0.8949-0.9826 & $0.0478-0.1101$ & $0.0022-0.0122$ \\
\hline \multirow{3}{*}{$\begin{array}{l}\text { Multiplication square } \\
\text { množenje } i \text { kvadratna } \\
Y=A_{\mathrm{w}} \cdot\left(A+B \cdot T+C \cdot T^{2}\right)\end{array}$} & 1 & $0.8870-0.9992$ & $0.0273-0.3529$ & $0.0007-0.1250$ \\
\hline & 2 & $0.8612-0.9986$ & $0.0214-0.3183$ & $0.0005-0.1014$ \\
\hline & 4 & $0.8629-0.9750$ & $0.0569-0.2753$ & $0.0032-0.0763$ \\
\hline \multirow{3}{*}{$\begin{array}{l}\text { Division and linear } \\
\text { dijeljenje } \text { i linearna } \\
Y=A_{\mathrm{w}} /(A+B \cdot T)\end{array}$} & 1 & $0.9202-0.9991$ & $0.0271-0.2839$ & $0.0007-0.0809$ \\
\hline & 2 & 0.9292-0.9992 & $0.0202-0.2361$ & 0.0004-0.0559 \\
\hline & 4 & $0.8198-0.9693$ & $0.0694-0.3082$ & $0.0048-0.0956$ \\
\hline \multirow{3}{*}{$\begin{array}{l}\text { Division and rational } \\
\text { dijeljenje i racionalna } \\
Y=A_{\mathrm{W}} /\left(A+B \cdot T^{-1}\right)\end{array}$} & 1 & $0.8450-0.9992$ & $0.0271-0.2706$ & $0.0007-0.0733$ \\
\hline & 2 & $0.8287-0.9987$ & $0.0201-0.2203$ & $0.0004-0.0486$ \\
\hline & 4 & $0.8195-0.9692$ & $0.0605-0.3012$ & $0.0036-0.0913$ \\
\hline $\begin{array}{l}\text { Division and logarithmic (common) } \\
\text { dijeljenje i logaritamska } \\
Y=A_{\mathrm{w}} /[A+B \cdot \log (T)]\end{array}$ & 1 & $0.9203-0.9992$ & $0.0271-0.2763$ & $0.0007-0.0766$ \\
\hline \multirow{4}{*}{$\begin{array}{l}\text { Division and square } \\
\text { dijeljenje } i \text { kvadratna } \\
Y=A_{\mathrm{w}} /\left(A+B \cdot T+C \cdot T^{2}\right)\end{array}$} & 1 & $0.8347-0.9992$ & $0.0276-0.3353$ & $0.0007-0.1043$ \\
\hline & 2 & $0.9288-0.9986$ & $0.0217-0.3229$ & $0.0005-0.1044$ \\
\hline & 4 & $0.8303-0.9754$ & $0.0481-0.2842$ & $0.0023-0.0755$ \\
\hline & 5 & $0.8569-0.9743$ & $0.0945-0.3344$ & $0.0053-0.1122$ \\
\hline
\end{tabular}

$R^{2}$ - determination coefficient / koeficijent determinacije; RMSE - root mean square error / korijen srednje vrijednosti kvadrata pogreške; $\chi^{2}$ reduced chi-square / reducirani hi-kvadrat

Table 3 Coefficients of parameter equations for chosen models of drying of spruce, beech, willow, and alder particles

Tablica 3. Koeficijenti parametarskih jednadžbi izabranih modela procesa sušenja iverja od drva smreke, bukve, vrbe i johe

\begin{tabular}{|c|c|c|c|c|c|c|c|c|c|}
\hline \multirow{2}{*}{$\begin{array}{l}\text { Model } \\
\text { No. } \\
\text { Broj } \\
\text { modela }\end{array}$} & \multirow{2}{*}{$\begin{array}{l}\text { Type of parameter } \\
\text { equation } \\
\text { Vrsta parametarske } \\
\text { jednadžbe }\end{array}$} & \multirow{2}{*}{\begin{tabular}{|} 
Param- \\
eter \\
Param- \\
etar
\end{tabular}} & \multicolumn{4}{|c|}{$A_{w}$} & \multirow[b]{2}{*}{$A$} & \multirow[b]{2}{*}{$B$} & \multirow[b]{2}{*}{$C$} \\
\hline & & & $\begin{array}{l}\text { Spruce } \\
\text { Smreka }\end{array}$ & $\begin{array}{l}\text { Beech } \\
B u k v a\end{array}$ & $\begin{array}{c}\text { Willow } \\
\text { Vrba }\end{array}$ & $\begin{array}{l}\text { Alder } \\
\text { Joha }\end{array}$ & & & \\
\hline 1 & $\begin{array}{l}\text { Summation (or subtrac- } \\
\text { tion) and logarithmic } \\
\text { (common) } \\
\text { zbrajanje (ili oduzimanje) } i \\
\text { logaritamska } \\
Y=A_{\mathrm{W}} \pm[A+B \cdot \log (T)]\end{array}$ & $k$ & 0.000929 & 0.001394 & 0.001858 & 0.000465 & -0.420312 & 0.169434 & - \\
\hline \multirow[b]{2}{*}{2} & \multirow{2}{*}{$\begin{array}{l}\text { Summation (or subtrac- } \\
\text { tion) and linear } \\
\text { zbrajanje (ili oduzimanje) } i \\
\text { linearna } \\
Y=A_{\mathrm{w}} \pm(A+B \cdot T)\end{array}$} & $k$ & 0.001319 & 0.001979 & 0.002639 & 0.000660 & -0.066479 & 0.000220 & - \\
\hline & & $a$ & 0.005172 & 0.007758 & 0.010344 & 0.002586 & 1.172629 & -0.000321 & - \\
\hline \multirow[b]{2}{*}{4} & \multirow{2}{*}{$\begin{array}{l}\text { Multiplication and square } \\
\text { množenje i kvadratna } \\
Y=A_{\mathrm{W}} \pm\left(A+B \cdot T+C \cdot T^{2}\right)\end{array}$} & $k$ & -0.000018 & -0.000026 & -0.000035 & -0.000009 & -2078.24 & 17.07 & -0.03 \\
\hline & & $n$ & -0.003710 & -0.005565 & -0.007420 & -0.001855 & -1296.87 & 5.73 & -0.01 \\
\hline \multirow[b]{2}{*}{5} & \multirow{2}{*}{$\begin{array}{l}\text { Division and square } \\
\text { dijeljenje } \text { i kvadratna } \\
Y=A_{\mathrm{W}} /\left(A+B \cdot T+C \cdot T^{2}\right)\end{array}$} & $a$ & -16.711 & -25.066 & -33.421 & -8.355358 & 220098.8 & -1103.3 & 1.4 \\
\hline & & $b$ & 0.106398 & 0.160 & 0.213 & 0.053199 & 2215636 & -11353 & 14 \\
\hline
\end{tabular}


reduced chi-square $\left(\chi^{2}\right)$ were examined for the applied models to compare their goodness of fit to the experimental drying data. It turned out that the effect of wood species and of drying air temperature on the drying model parameters can be considered individually (separated from one another). The following models: Lewis, Henderson and Pabis, and modified Page with the model parameters determined taking into account the effect of wood species and of drying air temperature were quite suitable for predicting the drying curve behaviour of spruce, beech, willow, and alder particles at the drying air temperature of $25,60,80$, and $150{ }^{\circ} \mathrm{C}$. For practical applications, Lewis model and Henderson and Pabis model can be recommended. Their goodness of fit to the experimental drying data is as follows: Lewis model: $R^{2}=0.8347-0.9998$, RMSE $=0.0203$ $-0.3529, \chi^{2}=0.0002-0.1250$ and Henderson and Pabis model: $R^{2}=0.8287-0.9998$, RMSE $=0.0200-$ $0.3229, \chi^{2}=0.0004-0.1044$.

\section{REFERENCES}

\section{LITERATURA}

1. Albrektas, D.; Ukvalbergienè, K., 2015: Impact of wood species dimension and drying temperature on sorption behaviour of wood. Drvna industrija, 66 (1): 3-10. http://dx.doi.org/10.5552/drind.2015.1369.

2. Bauer, K., 2003: Development and optimisation of a lowtemperature drying schedule for Eucalyptus grandis (Hill) ex Maiden in a solar - assisted timber dryer. PhD Thesis, Hohenheim University, Netherlands.

3. Chandra, P. K.; Singh, R. P., 1995: Applied numerical methods for food and agricultural engineers. Boca Raton, CRC Press, pp. 163-167.

4. Deliiski, N.; Syuleymanov, A., 2006: Influence of molar transfer coefficient on pressure distribution in beech lumber during its convective-vacuum drying. Drvna industrija, 57 (4): 165-170.

5. Dzurenda, L.; Deliiski, N., 2012: Convective drying of beech lumber without color changes of wood. Drvna industrija, 63 (2): 95-103.

http://dx.doi.org/10.5552/drind.2012.1135

6. Gigler, J. K.; van Loon, W. K. P.; van den Berg, J. V.; Sonneveld, C.; Meerdink, G., 2000: Natural wind drying of willow stems. Biomass and Bioenergy, 19 (3): 153163. http://dx.doi.org/10.1016/S0961-9534(00)00029-5.

7. Gómez-de la Cruz, F. J.; Casanova-Pelaez, P. J.; LópezGarcia, R.; Cruz-Peragón, F., 2015: Review of the drying kinetics of olive oil mill wastes: biomass recovery. BioResources, 10 (3): 6055-6080.

http://dx.doi.org/10.15376/biores.10.3.cruz

8. Henderson, S. M.; Pabis, S., 1961: Grain drying theory. I. Temperature effect on drying coefficient. Journal of Agricultural Engineering Research, 6 (3): 169-174.

9. Kajalavičius, A., 2008: Medienos hidroterminio apdorojimo teorija ir ịranga [Theory and equipment of wood hydrothermal processing]. Kaunas, Technologija 167 p. (in Lithuanian).

10. Kaleemullah, S.; Kailappan, R., 2005: Drying kinetics of red chillies in a rotary dryer. Biosystems Engineering, 92 (1): $15-23$. http://dx.doi.org/10.1016/j.biosystemseng.2005.05.015

11. Kaleta, A.; Górnicki, K., 2010: Some remarks on evaluation of drying models of red beet particles. Energy Conversion and Management, 51 (12): 2967-2978. http://dx.doi.org/10.1016/j.enconman.2010.06.040
12. Kaleta, A.; Górnicki, K.; Winiczenko, R.; Chojnacka, A., 2013: Evaluation of drying models of apple (var. Ligol) dried in a fluidized bed dryer. Energy Conversion and Management, 67 (12): 179-185.

http://dx.doi.org/10.1016/j.enconman.2012.11.011

13. Kashaninejad, M.; Mortazavi, A.; Safekordi, A.; Tabil, L. G., 2007: Thin-layer drying characteristics and modeling of pistachio nuts. Journal of Food Engineering, 78 (1): 98-108.

http://dx.doi.org/10.1016/j.jfoodeng.2005.09.007

14. Kohantorabi, M.; Hossein, A. M.; Shahverdi, M.; Roohnia, M., 2015: Vibration based NDT methods to verify wood drying efficiency. Drvna Industrija, 66 (3): 221-228. http://dx.doi.org/10.5552/drind.2015.1352

15. Lewis, W. K., 1921: The rate of drying of solid materials. Journal of Industrial and Engineering Chemistry, 13 (5): 427-432. http://dx.doi.org/10.1021/ie50137a021.

16. Overhults, D. G.; White, H. E.; Hamilton, H. E.; Ross, I. J., 1973: Drying soybean with heated air. Transaction of the ASAE, 16 (1): 112-113.

http://dx.doi.org/10.13031/2013.37459

17. Page, G. E., 1949: Factors influencing the maximum rates of air drying shelled corn in thin layers. MSc Thesis, Purdue University, USA.

18. Ståhl, M.; Granström, K; Berghel, J.; Renström, R., 2004: Industrial processes for biomass drying and their effects on the quality properties of wood pellets. Biomass and Bioenergy, 27 (6): 621-628. http://dx.doi.org/10.1016/j.biombioe.2003.08.019

19. Truscott, S. L.; Turner, I. W., 2005: A heterogeneous three-dimensional computational model for wood drying. Applied Mathematical Modelling, 29 (4): 381-410. http://dx.doi.org/10.1016/j.apm.2004.09.008

20. Turner, I. W., 1996: A two-dimensional orthotropic model for simulating wood drying processes. Applied Mathematical Modelling, 20 (1): 60-81. http://dx.doi.org/10.1016/0307-904X(95)00106-T

21. Wang, C. Y.; Singh, R. P., 1978: A single layer drying equation for rough rice. ASAE Paper No: 78-3001, ASAE St. Joseph, Mi.

22. Zarea Hosseinabadi, H.; Doosthoseini, K.; Layeghi, M., 2012: Drying kinetics of poplar (Populus Deltoides) wood particles by a convective thin layer dryer. Drvna industrija, 63 (3): 169-176. http://dx.doi.org/10.5552/drind.2012.1201

23. Zielińska, M.; Markowski, M., 2007: Drying behaviour of carrots dried in a spout - fluidized bed dryer. Drying Technology, 25 (1): 261-270. http://dx.doi.org/10.1080/07373930601161138

24. ***StatSoft, Inc. 2011. STATISTICA (data analysis software system), version 10. www.statsoft.com.

25. ***ASAE (American Society of Agricultural Engineers), 1994: Moisture measurements - forages, ASAE Standards, S3 58.2 DEC 93.

\section{Corresponding address:}

Assoc. Prof. KRZYSZTOF GÓRNICKI, Ph.D.

Warsaw University of Life Sciences

Faculty of Production Engineering

ul. Nowoursynowska 164

02-787 Warszawa, POLAND

e-mail: krzysztof_gornicki@sggw.pl 